\title{
Incorporation of $\mathrm{Bi}_{2} \mathrm{O}_{3}$ Residuals with Metallic $\mathrm{Bi}$ as High Performance Electrocatalyst toward Hydrogen Evolution Reaction
}

\author{
Rahmad Syah ${ }^{1}\left(\mathbb{D}\right.$, Awais Ahmad ${ }^{2, *}$, Afshin Davarpanah ${ }^{1} \mathbb{D}$, Marischa Elveny ${ }^{3, * \mathbb{D}}$, Dadan Ramdan ${ }^{1}$, \\ Munirah D. Albaqami ${ }^{4}$ and Mohamed Ouladsmane ${ }^{4} \mathbb{D}$
}

1 Data Science \& Computational Intelligence Research Group, Universitas Medan Area, Medan 20223, Indonesia; rahmadsyah@staff.uma.ac.id (R.S.); afshindpe@gmail.com (A.D.); dadan@uma.ac.id (D.R.)

2 Departamento de Quimica Organica, Universidad de Cordoba, Edificio Marie Curie (C-3), Ctra Nnal IV-A, Km 396, E14014 Cordoba, Spain

3 Data Science \& Computational Intelligence Research Group, Universitas Sumatera Utara, Medan 20154, Indonesia

4 Chemistry Department, College of Science, King Saud University, Riyadh 11451, Saudi Arabia; muneerad@ksu.edu.sa (M.D.A.); mouladsmane@ksu.edu.sa (M.O.)

* Correspondence: awaisahmed@gcuf.edu.pk (A.A.); marischaelveny@usu.ac.id (M.E.)

check for updates

Citation: Syah, R.; Ahmad, A.; Davarpanah, A.; Elveny, M.; Ramdan, D.; Albaqami, M.D.; Ouladsmane, M. Incorporation of $\mathrm{Bi}_{2} \mathrm{O}_{3}$ Residuals with Metallic Bi as High Performance Electrocatalyst toward Hydrogen Evolution Reaction. Catalysts 2021, 11, 1099. https://doi.org/10.3390/ catal11091099

Academic Editors: Chun-Chen Yang, Shen-Ming Chen, Prabhakarn

Arunachalam and Chelladurai Karuppiah

Received: 13 August 2021

Accepted: 8 September 2021

Published: 12 September 2021

Publisher's Note: MDPI stays neutral with regard to jurisdictional claims in published maps and institutional affiliations.

Copyright: (c) 2021 by the authors. Licensee MDPI, Basel, Switzerland. This article is an open access article distributed under the terms and conditions of the Creative Commons Attribution (CC BY) license (https:/ / creativecommons.org/licenses/by/ $4.0 /)$.

\begin{abstract}
Nanostructured Bismuth-based materials are promising electrodes for highly efficient electrochemical reduction processes such as hydrogen evolution reaction (HER). In this work, a novel sort of nanocomposite made up of partially reduced $\mathrm{Bi}_{2} \mathrm{O}_{3}$ into metallic $\mathrm{Bi}$ anchored on a 3D network of Ni-foam as a high-performance catalyst for electrochemical hydrogen reduction. The application of the hybrid material for HER is shown. The high catalytic activity of the fabricated electrocatalyst arises from the co-operative effect of $\mathrm{Bi} / \mathrm{Bi}_{2} \mathrm{O}_{3}$ and $\mathrm{Ni}$-foam which provides a highly effective surface area combined with the highly porous structure of $\mathrm{Ni}$-foam for efficient charge and mass transport. The advantages of the electrode for the electrochemical reduction processes such as high current density, low overpotential, and high stability of the electrode are revealed. An overall comparison of our as-prepared electrocatalyst with recently reported works on related work is done.
\end{abstract}

Keywords: bismuth-based electrocatalyst; water splitting; nanomaterials; electrocatalyst; hydrogen evolution reaction; electrochemistry

\section{Introduction}

Producing enough energy to meet our needs has become a crucial problem [1-14]. Demands are rising rapidly, due to the world's increasing population and expanding industry [15-28]. Burning fossil fuels, such as gas, coal, and oil, seriously damages the environment and they will eventually run out [29-42]. For many years, researchers have been working out how we can derive energy from renewable sources, therefore, water splitting has emerged [43-56]. It is a highly environmentally safe method to produce hydrogen as an energy source [57-70]. However, the electrochemical water splitting approach is in its first stages and needs further improvement in terms of overpotential for Hydrogen and Oxygen evolution reaction start [71-84] and demand for high performance materials to be performed at higher current density and high stability for operational works [84-87]. In this regard, it requires several efforts to be put forward to address these deficiencies to further improve the water-splitting process.

In recent decades, Bi-based catalysts [88] have been investigated numerous times because of their low cost, environmental friendliness, high electrochemical active sites and high electrocatalytic performance toward water splitting. In this regard, Bi-based catalysts can be synthesized through a facile electrodeposition route demonstrated influential catalytic performance for HER in neutral medium and was employed as a catalyst toward 
HER process with high efficacy and activity. In contrast, most Bi-based electrocatalysts usually suffer from low electrical conductivity, low active site densities, and dissolution or agglomeration during the electrochemical process which impedes long stability specifically at higher current densities [89]. Bi-based catalysts are generally believed to be the sort of materials that perform poorly toward HER. To address this issue, recent works have shown that synergy between the oxy/hydroxides structure such as the oxide phase of the transition metals with oxy/hydroxide blended phases poses high accessible surface area and so high performance toward HER, but they still suffer from low conductivity [90]. For example, Rachna et al. [91] have shown that the binary phase composed of oxy/hydroxide possesses higher catalytic activity than mono-phase (oxy or hydroxide). This is due to the excellent synergy effect between oxy/hydroxide phases which could result in lower Onsetpotential and overpotential toward water splitting. Besides that, many works have used conductive materials through hybridization with carbonic materials such as graphene flacks, carbon nanotubes (CNTs) [92], carbon quantum dots, and so on.

\section{Results}

The Ni-foam was employed as the platform for the growth of $\mathrm{Bi}_{2} \mathrm{O}_{3} / \mathrm{Bi}$ by hydrothermal approach. The deposition of $\mathrm{Bi}_{2} \mathrm{O}_{3} / \mathrm{Bi}$ on Ni-foam leads to a homogenous layer of the substrate by the nanoparticles without blocking the open pores of Ni-foam (Figure 1a,b). The SEM images in Figure 1a,b shows the product before calcination and Figure 1c,d demonstrate product micrographs after calcination. As can be seen, after and before calcination $\mathrm{Bi}_{2} \mathrm{O}_{3} / \mathrm{Bi}$ nanoparticles have a spherical morphology without further change (Figure 1c,d). The only changes can be ascribed to the particle sizes which the sizes of the particles are in the range of a few nanometers for particle before annealing and a few ten $\mathrm{nm}$ after annealing. As can be seen, there are small distances among nanoparticles while some of them are attached to each other [93]. Hydrogen bubbles release during the hydrothermal process would result in dendritic shape morphology or even changes in local $\mathrm{pH}$ at $\mathrm{Ni}$-foam surface which leads to a highly porous structure [94]. Moreover, during the hydrothermal process the following reactions would be occurred for the formation of oxidized Bi particles.

$$
\begin{gathered}
\mathrm{CO}\left(\mathrm{NH}_{2}\right)_{2} \rightarrow \mathrm{NH}_{3}+\mathrm{HCNO} \\
\mathrm{NH}_{3}+\mathrm{H}_{2} \mathrm{O} \rightarrow \mathrm{NH}_{4}^{+}+\mathrm{OH}^{-} \\
2 \mathrm{Bi}^{3+}+\mathrm{CO}_{3}^{2-}+4 \mathrm{OH}^{-} \rightarrow \mathrm{Bi}_{2} \mathrm{O}_{2} \mathrm{CO}_{3} \\
\mathrm{Bi}_{2} \mathrm{O}_{2} \mathrm{CO}_{3} \rightarrow \mathrm{Bi}_{2} \mathrm{O}_{3}
\end{gathered}
$$

HRTEM evaluations have shown that the fabricated nanoparticles are accumulated of fine particles given very high accessible active sites with high surface area (Figure 2a). The nature of the synthesized catalyst was proven through selected area electron diffraction (SAED) (the inset of Figure 2a) and X-ray diffraction (XRD) assessments (Figure 2b). XRD profile before calcination (Figure 2a black line) demonstrated a general Bi-based material with some weak peaks related to oxidized Bi. However, after calcination, we can see some strong peaks' presence which represents the production of oxidized Bi (orange line in Figure 2b). As it can be seen, a series of XRD peaks on the diffraction pattern of $\mathrm{Bi}_{2} \mathrm{O}_{3} / \mathrm{Bi}$ composition positioned at demonstrated $2 \theta$ at related miller indexes of (012), (107), (116), (214) and (009) at $2 \theta=28.5,59.5,63.5,72.5,73.2$, respectively. These miller indexes suggest a well-formed nanostructure of oxidized Bi with a rhombohedral polycrystalline Bi (JCPDS No. 85-1330). 


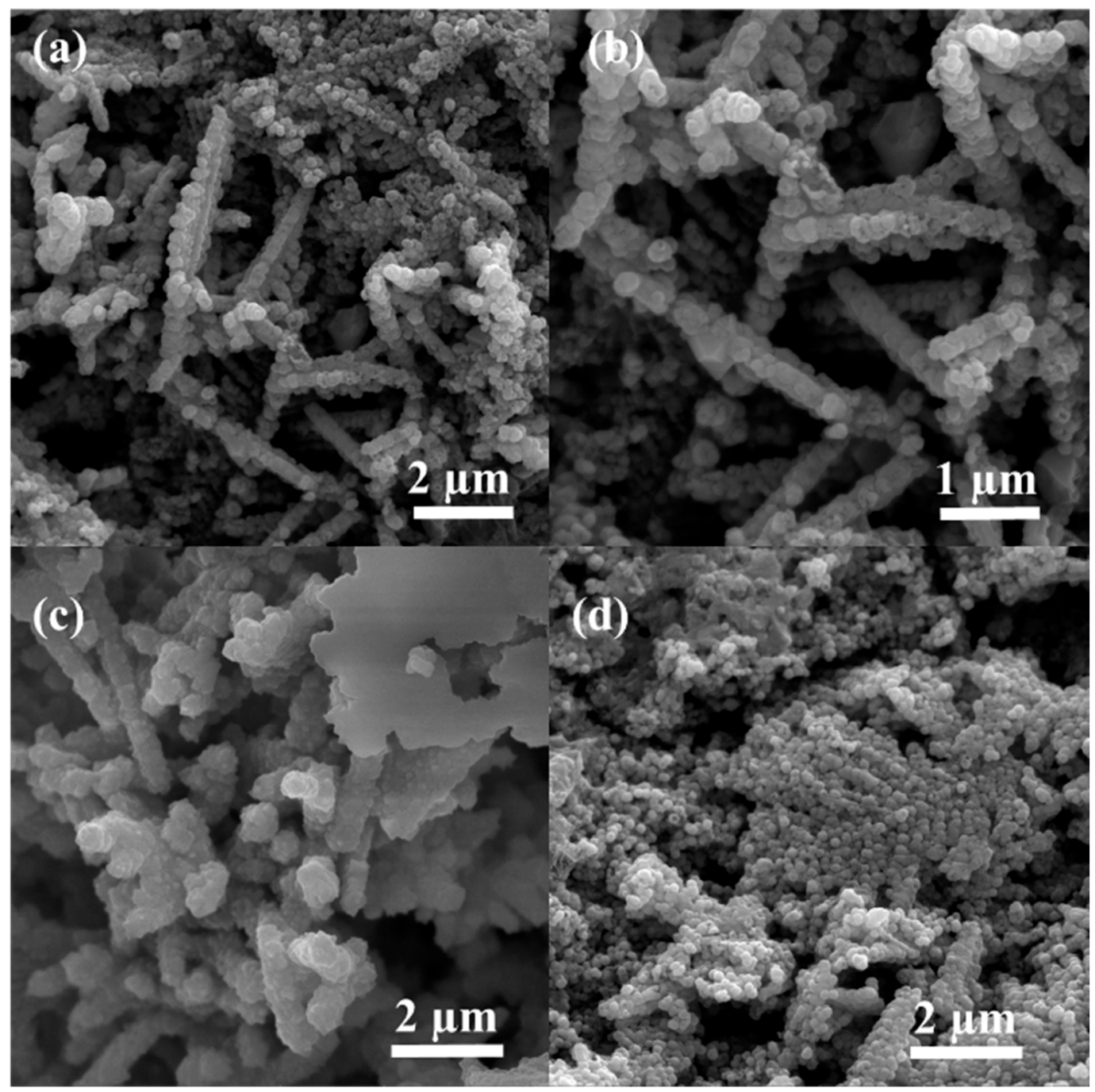

Figure 1. (a,b) SEM images before annealing at $500{ }^{\circ} \mathrm{C}$ show the open pore structure of $\mathrm{Bi}_{2} \mathrm{O}_{3} / \mathrm{Bi}$-Ni-foam; (c,d) SEM image shows the product images after the calcination process.
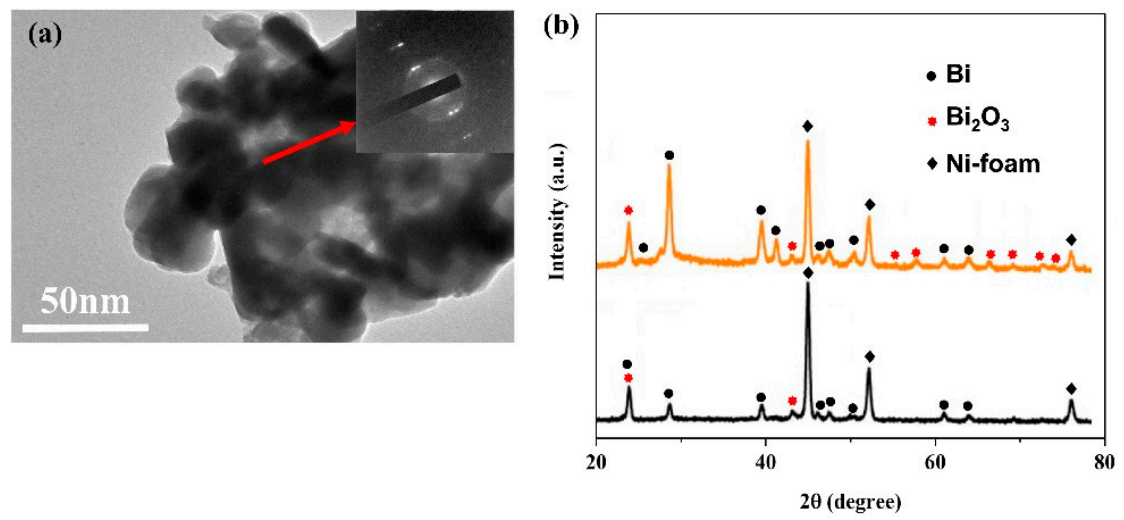

Figure 2. (a) HRTEM image of the prepared catalyst with related SAED spectra (the inside image), and (b) XRD profile of the prepared electrode before annealing (black line) after annealing (orange line).

Moreover, we used the common method (Debye-Scherrer formula) to estimate particle size by XRD profile 9, 17, 21. The formula is as follows:

$$
\mathrm{D}=(0.9 \lambda) /(\beta \cos (\theta))
$$


In the above-mentioned equation, $\lambda$ represents the X-ray wavelength (1.54 $\AA$ ), $\beta$ is the full width half maximum, $\theta$ is diffraction angle and $D$ is the particle size 21. The attained nanoparticle size of Bi before and after calcination is $\sim 8 \mathrm{~nm}$ and $\sim 26 \mathrm{~nm}$, respectively, which is in good agreement with SEM results. We have hypothesized that the fine nanoparticle of $\mathrm{Bi}_{2} \mathrm{O}_{3} / \mathrm{Bi}$ composition offers a highly accessible site for electrochemical reduction while the present pore structure enables mass transport in the solution during operation. On the other hand, metallic Ni-foam (as substrate) affords fast charge carriage while its porous construction comforts detachment and carriage of gaseous products from the electrode. To demonstrate the feasibility of the concept, we studied the electroactivity of the composite electrode for electroreduction of water. In order to demonstrate Bi oxidization influence, bare $\mathrm{Ni}$-foam and as-deposited Bi electrodes were tested. Electrochemical analysis via linear sweep voltammetry (LSV) displays in Figure 3a toward the HER process. The LSV curves of the $\mathrm{Bi}_{2} \mathrm{O}_{3} / \mathrm{Bi}$-NF as-prepared electrode demonstrated excellent HER activity with an overpotential of $180 \mathrm{mV}$ to reach $1 \mathrm{~mA} \cdot \mathrm{cm}^{-2}$. While the bare Ni-foam and Bi/NF electrodes showed a much higher overpotential of $240 \mathrm{mV}$ (for Ni-foam) and $215 \mathrm{mV}$ (for $\mathrm{Bi} / \mathrm{NF})$ at a current density of $1 \mathrm{~mA} \cdot \mathrm{cm}^{-2}$. Moreover, the optimized electrode $\left(\mathrm{Bi}_{2} \mathrm{O}_{3} / \mathrm{Bi}-\right.$ $\mathrm{NF}$ ) required a low overpotential of $250 \mathrm{mV}$ to reach a current of $10 \mathrm{~mA} \cdot \mathrm{cm}^{-2}$ while higher overpotentials of 300 and $370 \mathrm{mV}$ were required for $\mathrm{Bi} / \mathrm{NF}$ and $\mathrm{Ni}$-foam electrodes, respectively. This shows the prepared $\mathrm{Bi}_{2} \mathrm{O}_{3} / \mathrm{Bi}-\mathrm{NF}$ electrode had a much excellent HER performance than the other ones which could be due to the presence of partially reduced oxidized $\mathrm{Bi}$ at structure and not-reduced $\mathrm{Bi}_{2} \mathrm{O}_{3}$ at structure.

To further confirm HER kinetics, the Tafel slope was measured and considered for it, conformed to the Tafel formula (Figure $3 \mathrm{~b}$ ) were constructed according to the following Equations (6) and (7):

$$
\begin{gathered}
\eta=b \cdot \log (j)+a \\
b=2.303 R T /(\propto Z F)
\end{gathered}
$$

In above-mentioned Equations (6) and (7), $\eta$ demonstrate overpotentials and $j$ also shows current density. In addition, a mechanistic demonstration of electrochemical reactions can be shown by $\alpha$ which is charge transfer coefficient and is a constant. The slope of $\eta$-j curve (the cathodic Tafel slope) defines the rate of electrochemical reaction. The value of $j$ at $\eta=0$ is related to exchange current density $\left(j_{0}\right)$, which is an important parameter for assessing catalytic activity of a catalyst for water reduction reaction. As can be carried out from the Tafel plot, a lower Tafel slope would result in sharper growth of increasing overpotential 24. As can be seen from Figure $3 \mathrm{~b}$, the $\mathrm{Bi}_{2} \mathrm{O}_{3} / \mathrm{Bi}-\mathrm{NF}$ electrode demonstrated a lower Tafel slope of $55 \mathrm{mV} / \mathrm{dec}$ which is smaller than that of Bi/NF and Ni-foam electrodes with Tafel slopes of 123 and $115 \mathrm{mV} / \mathrm{dec}$, respectively.

In addition to the above-mentioned discussion, the following multistep reactions could be considered for this work, though HER kinetics has not been well-understood up until now $[13,20]$ :

$$
\begin{gathered}
\mathrm{H}_{2} \mathrm{O}+\mathrm{M}+\mathrm{e}^{-} \rightarrow \mathrm{MH}_{\mathrm{ads}}+\mathrm{Oe}^{-} \text {(Volmer step; discharge reaction) } \\
\mathrm{MH}_{\mathrm{ads}}+\mathrm{MH}_{\mathrm{ads}} \rightarrow \mathrm{H}_{2}+2 \mathrm{M} \text { (Tafel step; recombination reaction) } \\
\mathrm{H}_{2} \mathrm{O}+\mathrm{MH}_{\mathrm{ads}}+\mathrm{e}^{-} \rightarrow \mathrm{H}_{2}+\mathrm{M}+\mathrm{OH}^{-} \text {(Heyrovsky step) }
\end{gathered}
$$

" $\mathrm{M}$ " stands for active sits for $\mathrm{H}$ adsorption. The process is begun with the Volmer step (Equation (8)) where the first discharge includes on the electrode surface by adsorbing water molecules. Then, catalytic recombination of adsorbed protons (Equation (9)) and the electro-desorption of adsorbed intermediates (Equation (10)) take place. Based on the Tafel slope, which is in the range of $40-120 \mathrm{mV} / \mathrm{dec}$, we believe that the HER process can be controlled by the Volmer-Heyrovsky mechanism in Equations (9) and (10). 
(a)

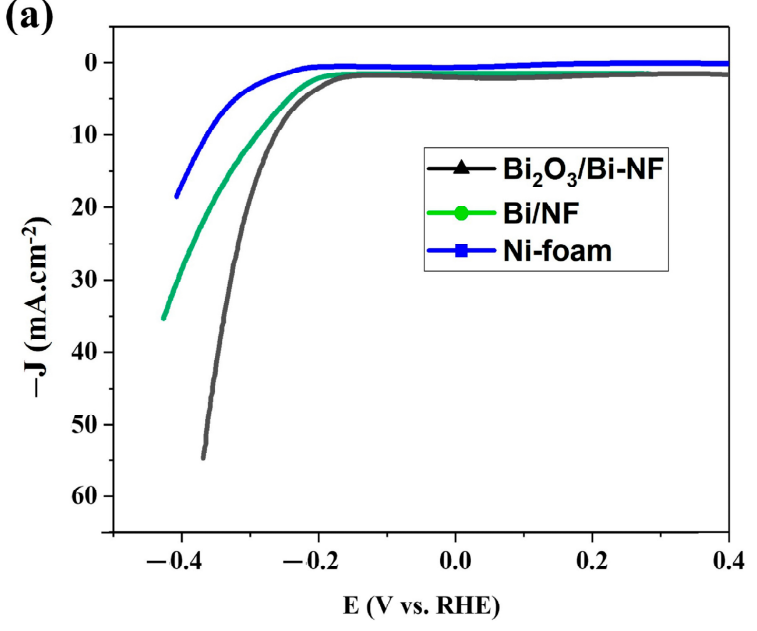

(c)

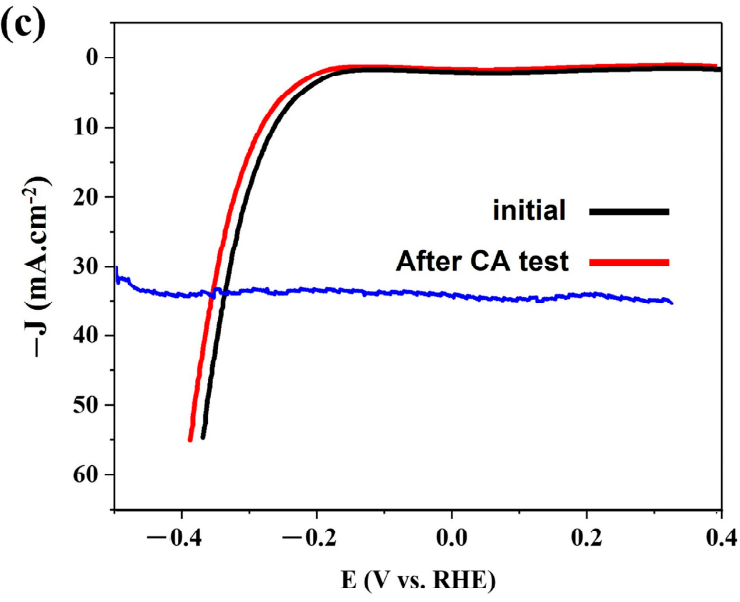

(b)

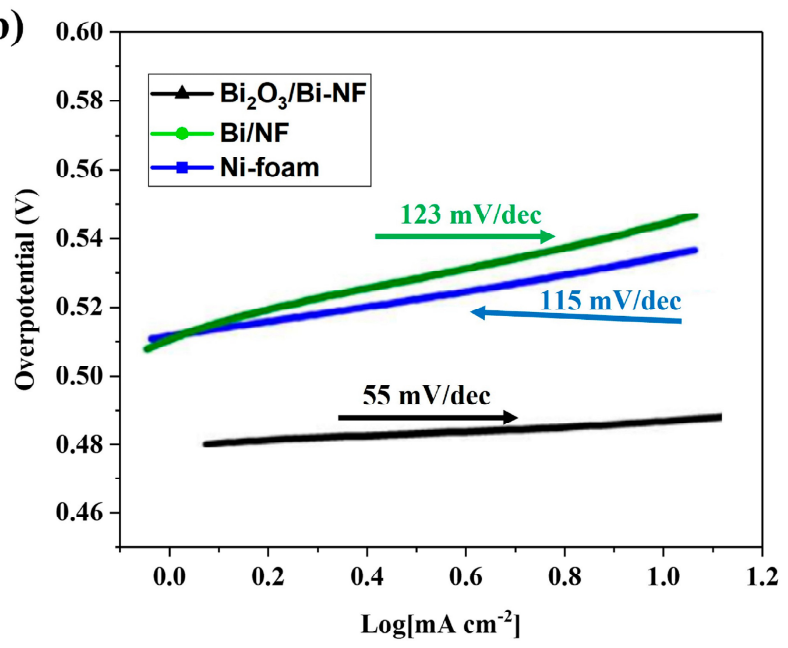

(d)

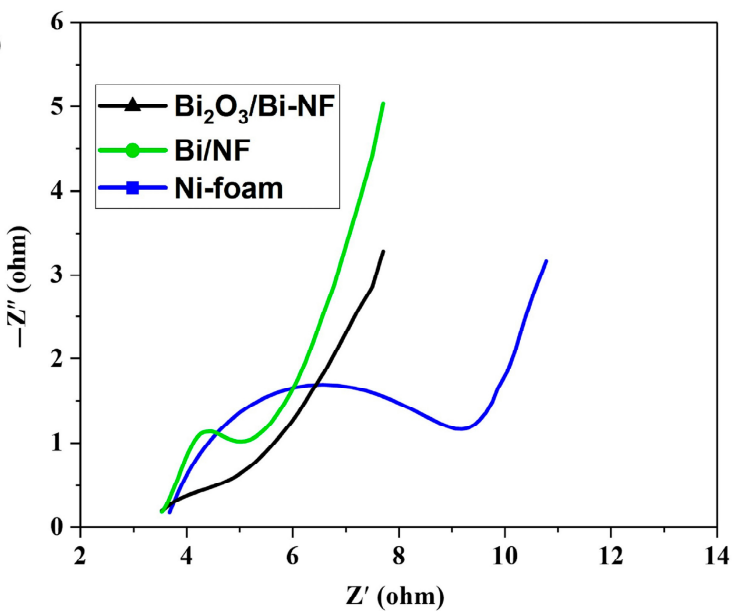

Figure 3. Electrochemical characterizations of the hybrid electrocatalyst. (a) iR-corrected LSV results for the prepared electrodes at $5 \mathrm{mV} / \mathrm{s}$ in $1.0 \mathrm{M} \mathrm{KOH}$; (b) related Tafel slope for the prepared electrodes; (c) stability of $\mathrm{Bi}_{2} \mathrm{O}_{3} / \mathrm{Bi}^{-\mathrm{NF}}$ electrode before (the red line) and after (the black line) about $4 \mathrm{~h}$ measured (the blue line) in $1.0 \mathrm{M} \mathrm{KOH}$ at $-1.35 \mathrm{~V}(\mathrm{Ag} / \mathrm{AgCl})$ and (d) Nyquist results for the prepared electrodes at OCP.

We examined the stability of the optimized $\mathrm{Bi}_{2} \mathrm{O}_{3} / \mathrm{Bi}$-NF electrocatalyst in the basic electrolyte by CA (the blue line in Figure 3c). The HER stability tests were conducted uninterruptedly from one sample. Changes in the current density in LSV curve are shown in Figure $3 \mathrm{c}$ (the red and black line). As seen, the $\mathrm{Bi}_{2} \mathrm{O}_{3} / \mathrm{Bi}-\mathrm{NF}$ electrocatalyst reveals high durability with negligible changes in the current response. This shows good connection between $\mathrm{Bi}_{2} \mathrm{O}_{3} / \mathrm{Bi}$ particles and Ni-foam platform. Microstructural studies by SEM and $\mathrm{XRD}$ have shown some changes in the surface morphology and a little change in the structure of the $\mathrm{Bi}_{2} \mathrm{O}_{3} / \mathrm{Bi}-\mathrm{NF}$ due to the oxidized $\mathrm{Bi}$ reduction into metallic $\mathrm{Bi}$ of the electrodeposited alloy after CA. As can be seen from Figure $4 \mathrm{a}$, the SEM image shows surface agglomeration which might be due to the reduced $\mathrm{Bi}_{2} \mathrm{O}_{3}$ into metallic form and tend to be agglomerate. The structural changes can be carried out from faded XRD peaks or weakened peaks in Figure $4 \mathrm{~b}$. As can be seen from Figure $4 \mathrm{~b}$, most of the oxidized Bi have been weakened or faded which is as a result of applied reduced potential during HER process. In order to further confirm this result, EDS analysis has been applied to detect the percentage of each element. As can be seen from Figure 4e, more than $80 \%$ is metallic $\mathrm{Bi}$, while only a small portion contains Oxygen elements. 

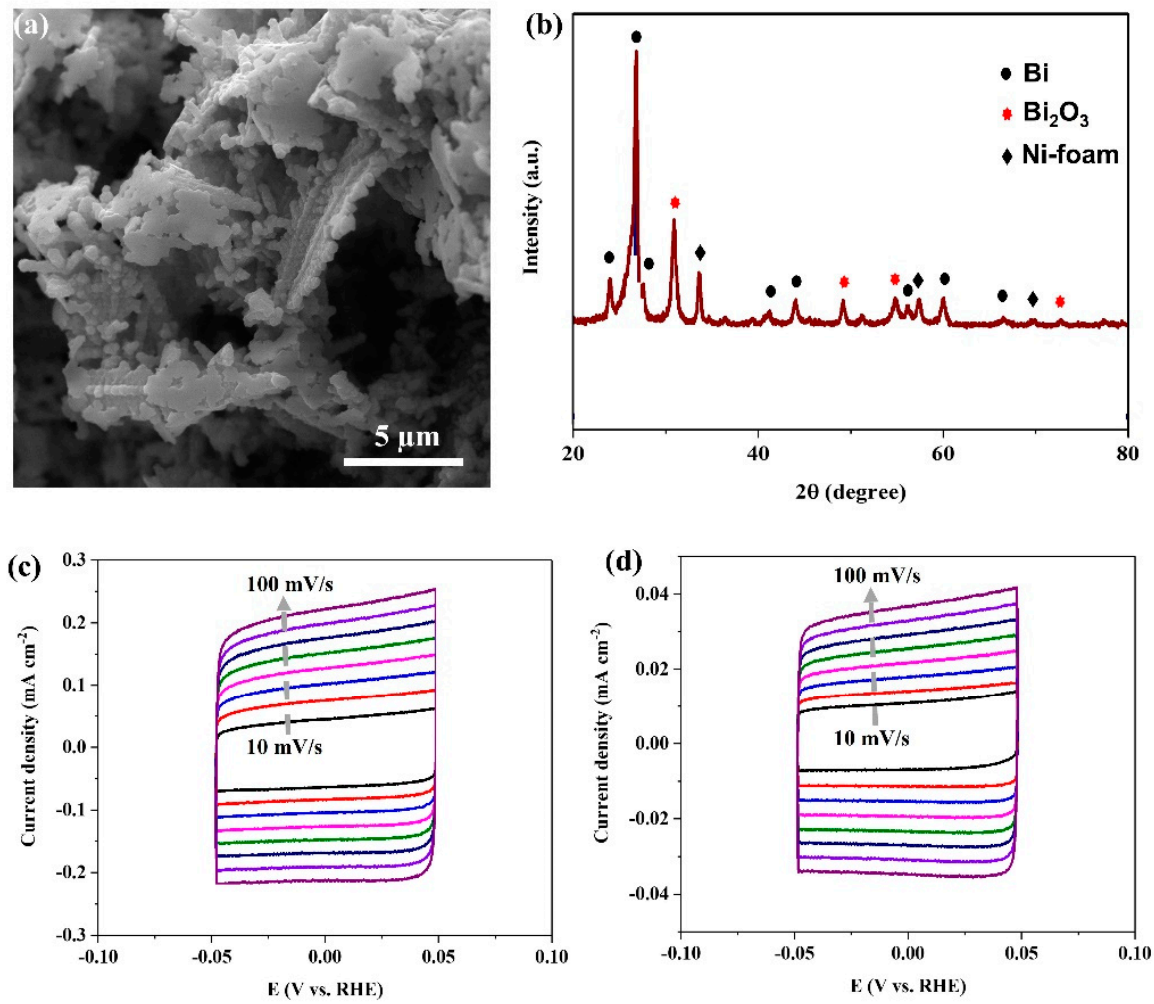

(e)

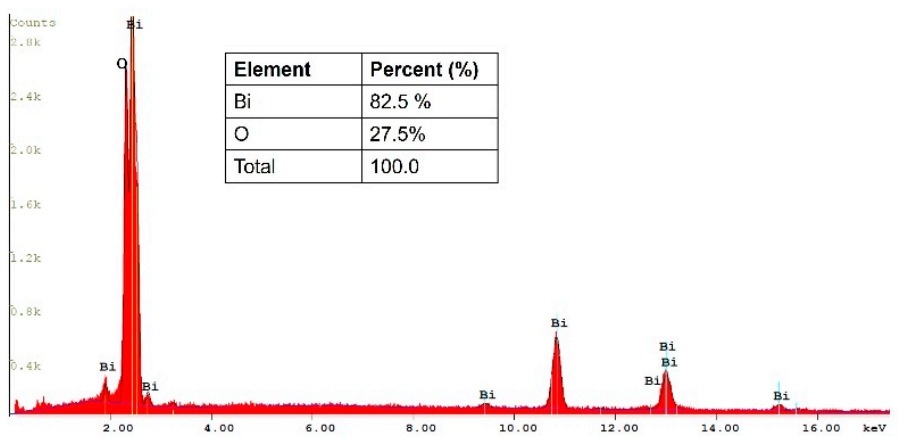

Figure 4. (a) SEM image after long-term stability test; (b) XRD analysis after stability test from $\mathrm{Bi}_{2} \mathrm{O}_{3} / \mathrm{Bi}-\mathrm{NF}$ electrode; (c,d) CV curves at different scan rates (10 to $\left.100 \mathrm{mV} / \mathrm{s}\right)$ for $\mathrm{Bi}_{2} \mathrm{O}_{3} / \mathrm{Bi}-\mathrm{NF}$ and $\mathrm{Ni}$-foam, respectively and (e) EDS illustration of the elemental composition of the electrode after HER stability test.

Electrochemical impedance spectroscopy (EIS) is conducted to study charge transfer behavior of the catalyst, which is shown by Nyquist plots (Figure 3d). A depressed semicircle can be associated with charge-transfer-controlled effect. Fluctuations in impedance waves could be associated with gaseous product release from the catalyst surface that could generate forced convection and disturb the ionic or electron transfer [94-96]. We have found that $\mathrm{Bi}_{2} \mathrm{O}_{3}$ growth and deposition on $\mathrm{Ni}$-foam intensely lessening charge transfer resistance (denoted as $\mathrm{R}_{\mathrm{ct}}$ ) of the combined $\mathrm{Bi}_{2} \mathrm{O}_{3} / \mathrm{Bi}-\mathrm{NF}$ electrode which results in conductivity enhancement of the electrode. The $\mathrm{Bi}_{2} \mathrm{O}_{3} / \mathrm{Bi}-\mathrm{NF}$ electrode showed a small charge transfer resistance (small semi-circle). It is worth noting that the root cause of this is related to the large accessible active sites for doing reduction reaction on the catalyst surface and also good connection between electrode materials for charge transfer. Moreover, it might be due to this reason that the decent electrode material and electrolyte interfacial area could further decrease the resistance for charge transport [97]. Besides, it is seen that co-catalyzing of $\mathrm{Bi}_{2} \mathrm{O}_{3}$ with $\mathrm{Bi}$ and $\mathrm{Ni}$ foam also offers rapid charge transport due to more accessible active sites on electrode surface as reinforced by the double-layer capacitance measurements (Figure $4 \mathrm{c}, \mathrm{d}$ ). There is an ion diffusion limitation linking to the Warburg behavior at low 
frequencies (Figure 3d) [98]. Further evaluations by EIS at OCP have shown that the ion diffusion at $\mathrm{Bi}_{2} \mathrm{O}_{3} / \mathrm{Bi}-\mathrm{NF}$ surface is controlled by diffusion of $\mathrm{OH}^{-}$ions (with limited diffusion rate) between the electrolyte and the electrode interface. Figure 4 determines that the composition of $\mathrm{Bi}_{2} \mathrm{O}_{3}$ in combination with $\mathrm{Bi} / \mathrm{NF}$ reduces the diffusion resistance of $\mathrm{Ni}$-foam assigning to their co-operative and synergy effect exposed to the alkaline solution that provides a low distance and rapid ion diffusion. In addition, those nanoparticles could reduce the hydrophobicity of overall structure assisting to the diffusion resistance [99].

Capacitance and effective electrocatalytic surface area. To evaluate electrochemical surface area (ECSA), CV technique was employed at various scan rates (10 to $100 \mathrm{mV} / \mathrm{s}$ ) and double layer capacitance (Cd) was calculated by the following formula [100-106]:

$$
\begin{gathered}
\mathrm{S}=\int_{-0.5}^{0.5} i d v \\
\mathrm{C}_{\mathrm{dl}}=\mathrm{S} /(v \Delta \mathrm{V})
\end{gathered}
$$

In Equations (11) and (12), $i$ represents non-Nernst current and $v$ is the scan rate. $S$ stands for the attained surface area by integration CV plot. Equations (11) and (12) are utilized to measure $\mathrm{C}_{\mathrm{dl}}$ (double layer capacitance) from voltammetry plot where there is not any faradaic charge transfer. It is used to compare electrochemically active surface area of provided electrodes (in this work the electrodes are $\mathrm{Bi}_{2} \mathrm{O}_{3} / \mathrm{Bi}-\mathrm{NF}$ and Ni-foam). As a result of this calculation, we have obtained a $\mathrm{C}_{\mathrm{dl}}$ of $1.2 \mathrm{mF} \cdot \mathrm{cm}^{-2}$ for $\mathrm{Bi}_{2} \mathrm{O}_{3} / \mathrm{Bi}-\mathrm{NF}$ and a $\mathrm{C}_{\mathrm{dl}}$ of $0.095 \mathrm{mF} \cdot \mathrm{cm}^{-2}$ for Ni-foam. Which this result shows $\mathrm{Bi}_{2} \mathrm{O}_{3} / \mathrm{Bi}-\mathrm{NF}$ higher ECSA than $\mathrm{Ni}$-foam which is in good agreement with those LSV results. It is worth noting that the capacitance is proportionate to the ECSA for adsorption/desorption of electrolyte ion. To investigate the effect of ECSA of catalysts for HER, it is thus helpful to investigate the ECSA of different catalysts. The acquired $\mathrm{C}_{\mathrm{dl}}$ of catalysts $\left(\mathrm{Bi}_{2} \mathrm{O}_{3} / \mathrm{Bi}-\mathrm{NF}\right.$ and $\mathrm{Ni}$-foam) have been assessed as shown in Figure $4 \mathrm{c}$,d. Therefore, the $\mathrm{Bi}_{2} \mathrm{O}_{3} / \mathrm{Bi}-\mathrm{NF}$ electrocatalyst displayed a considerably higher $\mathrm{Cdl}$, which is satisfactory for the essentially promoted HER activity of this catalyst.

\section{Materials and Methods}

\subsection{Materials}

Bismuth (III) nitrate pentahydrate $\left(\mathrm{Bi}\left(\mathrm{NO}_{3}\right) 3.5 \mathrm{H}_{2} \mathrm{O}, 99 \%\right)$, Nitric acid $\left(\mathrm{HNO}_{3}, 99 \%\right)$, urea $\left(\mathrm{CO}\left(\mathrm{NH}_{2}\right)_{2}, 99 \%\right)$, Sulfuric acid $\left(\mathrm{H}_{2} \mathrm{SO}_{4}, 95-98 \%\right)$, Potassium hydroxide $(\mathrm{KOH}, 99 \%)$, Hydrochloric Acid $(\mathrm{HCl}, 37 \%)$, Sodium hydroxide $(\mathrm{NaOH})$, and high quality Ni foam ( $99.5 \%$ purity with $95 \%$ porosity) were obtained from Merck (Darmstadt, Germany). Deionized water (DI) was provided by the local market. Ethanol (96\%), and acetone (99\%) were purchased from Sigma Aldrich (Merck).

\subsection{Fabrication of Oxidized $\mathrm{Bi}\left(\mathrm{Bi}_{2} \mathrm{O}_{3}\right)$}

Pieces of $2 \times 4 \mathrm{~cm}^{2}$ from $\mathrm{Ni}$ foam were prepared through laser cutting and the prepared pieces were washed with acetone and ethanol sonicated for $10 \mathrm{~min}$, respectively. As prepared samples dried under an Ar gas atmosphere and put inside a quartz boat to be dried at $60^{\circ} \mathrm{C}$. Afterward, a facile and reproducible hydrothermal route was employed to synthesize $\mathrm{Bi}_{2} \mathrm{O}_{3}$. In a general process, $1 \mathrm{mmol}$ of $\mathrm{Bi}\left(\mathrm{NO}_{3}\right) 3.5 \mathrm{H}_{2} \mathrm{O}$ was added into $10 \mathrm{~mL}$ of $2.5 \mathrm{M} \mathrm{HNO}_{3}$ aqueous solution, the $\mathrm{Bi}\left(\mathrm{NO}_{3}\right) 3.5 \mathrm{H}_{2} \mathrm{O}$ solution was added gradually. Then, we added the prepared solution into a $30 \mathrm{~mL}$ solution containing $5 \mathrm{mmol}$ urea. Therefore, after vigorous blending for $30 \mathrm{~min}, 10 \mathrm{~mL}$ of $3 \mathrm{M}$ sodium hydroxide was added gradually into the prepared solution. After extra stirring for $20 \mathrm{~min}$, the prepared solution along with Ni-foam pieces was transferred into a stainless-steel autoclave with a $50 \mathrm{~mL}$ capacity Teflon liner. The autoclave containing all prepared solution was heated at $100^{\circ} \mathrm{C}$ for $20 \mathrm{~h}$. The heating ramp was set up at $3{ }^{\circ} \mathrm{C} / \mathrm{min}$. Afterward, the autoclave was taken out from the furnace and cooled to ambient temperature. The Ni-foam was taken out from the autoclave and washed several times with ethanol and DI water. The remaining products 
in the container were also separated through centrifugation and cleaned with DI water and ethanol and methanol three times in each step (in order to get rid of contaminated species), respectively. Then the product was dried under Ar gas flow for $10 \mathrm{~h}$ at $50{ }^{\circ} \mathrm{C}$ in a tube furnace. Afterward, the prepared product was annealed at $500{ }^{\circ} \mathrm{C}$ for $2 \mathrm{~h}$ under air condition. The calcination process has been applied to oxidizing metallic Bi.

\subsection{Materials Characterizations}

Powder X-ray diffraction (XRD) patterns were recorded on an X-ray diffractometer (Philips, X'pert PRO, Amsterdam, The Netherlands) by using Cu K $\alpha$ radiation $(\lambda=1.541874 \AA)$ at a scanning rate of $7^{\circ} / \mathrm{min}$ in the $2 \theta$ range from $20^{\circ}$ to $80^{\circ}$. High Resolution Transmission Electron Microscope (HRTEM, JOEL JEM-2010F, Singapore) and a Scanning Electron Microscope (SEM, MIRA III TESCAN, Kohoutovice, Czech Republic) equipped with Energydispersive X-ray spectroscopy (EDX) is a surface analytical technique used to investigate microstructural and morphological properties.

\subsection{Electrochemical Evaluations}

All electrochemical tests for the HER process were conducted by an Autolab PGSTAT 302 N electrochemical workstations (Metrohm Autolab, Amsterdam, The Netherlands) with a standard three-electrode system in $1 \mathrm{M} \mathrm{KOH}$ aqueous solution. The working electrode was $\mathrm{Bi}_{2} \mathrm{O}_{3} / \mathrm{Bi}$ deposited on $\mathrm{Ni}$-foam $\left(\mathrm{Bi}_{2} \mathrm{O}_{3} / \mathrm{Bi}-\mathrm{NF}\right)$ electrocatalysts with a size of $\sim$ one $\mathrm{cm}^{2}$. A platinum plate as counter electrode and $\mathrm{Ag} / \mathrm{AgCl}(3 \mathrm{M} \mathrm{KCl})$ as the reference electrode were employed. Linear Sweep Voltammetry (LSV) observations have been conducted with a scan rate of $5 \mathrm{mVs}^{-1}$ in a potential range of 0 to $-1.5 \mathrm{~V}$ (vs. $\mathrm{Ag} / \mathrm{AgCl}$ ). CA measurement was applied at $-1.35 \mathrm{~V}$ (vs. $\mathrm{Ag} / \mathrm{AgCl}$ ) to discover the optimized electrode's durability. Moreover, the charge and ionic transfer and diffusion performance of the prepared electrodes were evaluated through Electrochemical Impedance Spectroscopy (EIS) over a frequency range of $10^{-1} \mathrm{~Hz}$ to $10^{5} \mathrm{~Hz}$ and at open circuit potential (OCP) with a $10 \mathrm{mV}$ sinusoidal potential. All the potentials conveyed in this work were referenced to RHE by the addition of $(0.197+0.059 \mathrm{pH} 8)$. iR-correction was also done [92]. The compensated potential was considered by $E_{\text {compensated }}=E_{\text {measured }}+I \times R_{s}$, where $R_{s}$ is the series resistance obtained by EIS data [93].

\section{Conclusions}

In summary, Bi-based catalysts were synthesized on spongy Ni-foam to prepare active electrochemical material for the HER process. To exhibit the high electrocatalytic performance, the high activity of the $\mathrm{Bi}_{2} \mathrm{O}_{3} / \mathrm{Bi}-\mathrm{NF}$ electrode for the reduction of water in basic electrolytes was revealed. For HER, the general comparative current density $10 \mathrm{~mA} \cdot \mathrm{cm}^{-2}$ was reached at a low overpotential of $250 \mathrm{mV}$ as shown. Furthermore, the evaluations through EIS technique analyses demonstrated rapid HER kinetics with a low Tafel slope $55 \mathrm{mV} / \mathrm{dec}$ for $\mathrm{Bi}_{2} \mathrm{O}_{3} / \mathrm{Bi}-\mathrm{NF}$ as a result of the co-operative effect of oxidized $\mathrm{Bi}$ and metallic $\mathrm{Bi}$ in the catalyst structure. These high electrochemical activities proposed highly cooperative effects of oxidized $\mathrm{Bi}$ and metallic $\mathrm{Bi}$ and $\mathrm{Ni}$-foam substrate on the electrocatalytic performance. Specifically, high electron transport originating from 3D porous structure, that also helped reduce ion diffusion alongside the catalyst surface. Therefore, it can be said that the $\mathrm{Bi}_{2} \mathrm{O}_{3} / \mathrm{Bi}-\mathrm{NF}$ catalyst could offer a good approach for future research in electrochemical redox-reaction, e.g., water splitting and even in electrochemically reduction of $\mathrm{CO}_{2}$ into value added feedstocks.

Author Contributions: R.S. and A.A. have conceptualized, synthesized and characterized the samples, designed experimental tests and performed electrochemical experiments, analyzed the obtained data from all electrochemical tests and characterization evaluations, and prepared the first and original draft of the manuscript and responded to the revision process. A.D. and M.E. contributed to experimental design, data analysis and manuscript preparation. D.R. was involved in data analysis and manuscript preparation. M.D.A. and D.R contributed to manufacturing samples and contributed to the manuscript preparation. M.O. contributed to TEM analysis. A.D supervised the research, de- 
veloped concepts and methodologies, provided resources and acquisitions, and edited and finalized the manuscript. All authors have read and agreed to the published version of the manuscript.

Funding: This research received no external funding.

Acknowledgments: This work was funded by the Researchers Supporting Project Number (RSP2021/267) King Saud University, Riyadh, Saudi Arabia.

Conflicts of Interest: The authors declare no conflict of interest.

\section{References}

1. Chen, H.; Heidari, A.A.; Chen, H.; Wang, M.; Pan, Z.; Gandomi, A.H. Multi-population differential evolution-assisted Harris hawks optimization: Framework and case studies. Futur. Gener. Comput. Syst. 2020, 111, 175-198. [CrossRef]

2. Wang, M.; Chen, H. Chaotic multi-swarm whale optimizer boosted support vector machine for medical diagnosis. Appl. Soft Comput. 2020, 88. [CrossRef]

3. Xu, Y.; Chen, H.; Luo, J.; Zhang, Q.; Jiao, S.; Zhang, X. Enhanced Moth-flame optimizer with mutation strategy for global optimization. Inf. Sci. 2019, 492, 181-203. [CrossRef]

4. He, L.; Li, M.-X.; Chen, F.; Yang, S.-S.; Ding, J.; Ding, L.; Ren, N.-Q. Novel coagulation waste-based Fe-containing carbonaceous catalyst as peroxymonosulfate activator for pollutants degradation: Role of ROS and electron transfer pathway. J. Hazard. Mater. 2021, 417, 126113. [CrossRef] [PubMed]

5. Li, Z.; Shi, Y.; Zhu, A.; Zhao, Y.; Wang, H.; Binks, B.P.; Wang, J. Light-Responsive, Reversible Emulsification and Demulsification of Oil-in-Water Pickering Emulsions for Catalysis. Angew. Chem. Int. Ed. 2020, 60, 3928-3933. [CrossRef]

6. Huang, W.-Y.; Wang, G.-Q.; Li, W.-H.; Li, T.-T.; Ji, G.-J.; Ren, S.-C.; Jiang, M.; Yan, L.; Tang, H.-T.; Pan, Y.-M.; et al. Porous Ligand Creates New Reaction Route: Bifunctional Single-Atom Palladium Catalyst for Selective Distannylation of Terminal Alkynes. Chem 2020, 6, 2300-2313. [CrossRef]

7. Duan, Y.; Liu, Y.; Chen, Z.; Liu, D.; Yu, E.; Zhang, X.; Fu, H.; Fu, J.; Zhang, J.; Du, H. Amorphous molybdenum sulfide nanocatalysts simultaneously realizing efficient upgrading of residue and synergistic synthesis of 2D MoS2 nanosheets/carbon hierarchical structures. Green Chem. 2019, 22, 44-53. [CrossRef]

8. Xu, G.; Ling, R.; Deng, L.; Wu, Q.; Ma, W. Image Interpolation via Gaussian-Sinc Interpolators with Partition of Unity. Comput. Mater. Contin. 2020, 62, 309-319. [CrossRef]

9. He, S.; Li, Z.; Tang, Y.; Liao, Z.; Li, F.; Lim, S.-J. Parameters Compressing in Deep Learning. Comput. Mater. Contin. 2020, 62, 321-336. [CrossRef]

10. Guo, W.; Liu, T.; Dai, F.; Xu, P. An Improved Whale Optimization Algorithm for Feature Selection. Comput. Mater. Contin. 2020, 62, 337-354. [CrossRef]

11. Vijayalakshmi, K.; Anandan, P. Global levy flight of cuckoo search with particle swarm optimization for effective cluster head selection in wireless sensor network. Intell. Autom. Soft Comput. 2020, 26, 303-311. [CrossRef]

12. Huang, D.H.; Gu, P.; Feng, H.-M.; Lin, Y.; Zheng, L. Robust Visual Tracking Model Designs Through Kernelized Correlation Filters. Intell. Autom. Soft Comput. 2019, 26, 313-322. [CrossRef]

13. Sezer, O.; Ozbayoglu, A. Financial Trading Model with Stock Bar Chart Image Time Series with Deep Convolutional Neural Networks. Intell. Autom. Soft Comput. 2020, 26, 323-334. [CrossRef]

14. Zhao, X.; Zhang, X.; Cai, Z.; Tian, X.; Wang, X.; Huang, Y.; Chen, H.; Hu, L. Chaos enhanced grey wolf optimization wrapped ELM for diagnosis of paraquat-poisoned patients. Comput. Biol. Chem. 2019, 78, 481-490. [CrossRef] [PubMed]

15. Li, C.; Hou, L.; Sharma, B.Y.; Li, H.; Chen, C.; Li, Y.; Zhao, X.; Huang, H.; Cai, Z.; Chen, H. Developing a new intelligent system for the diagnosis of tuberculous pleural effusion. Comput. Methods Programs Biomed. 2018, 153, 211-225. [CrossRef]

16. Wang, M.; Chen, H.; Yang, B.; Zhao, X.; Hu, L.; Cai, Z.; Huang, H.; Tong, C. Toward an optimal kernel extreme learning machine using a chaotic moth-flame optimization strategy with applications in medical diagnoses. Neurocomputing 2017, $267,69-84$. [CrossRef]

17. Guan, H.; Huang, S.; Ding, J.; Tian, F.; Xu, Q.; Zhao, J. Chemical environment and magnetic moment effects on point defect formations in CoCrNi-based concentrated solid-solution alloys. Acta Mater. 2020, 187, 122-134. [CrossRef]

18. Zhang, M.; Zhang, L.; Tian, S.; Zhang, X.; Guo, J.; Guan, X.; Xu, P. Effects of graphite particles/Fe3+ on the properties of anoxic activated sludge. Chemosphere 2020, 253, 126638. [CrossRef]

19. Cheng, J.-Z.; Tan, Z.-R.; Xing, Y.-Q.; Shen, Z.-Q.; Zhang, Y.-J.; Liu, L.-L.; Yang, K.; Chen, L.; Liu, S.-Y. Exfoliated conjugated porous polymer nanosheets for highly efficient photocatalytic hydrogen evolution. J. Mater. Chem. A 2021, 9, 5787-5795. [CrossRef]

20. Ren, S.; Ye, B.; Li, S.; Pang, L.; Pan, Y.; Tang, H. Well-defined coordination environment breaks the bottleneck of organic synthesis: Single-atom palladium catalyzed hydrosilylation of internal alkynes. Nano Res. 2021, 1-9. [CrossRef]

21. Tümer, A.E.; Akkus, A. Application of radial basis function networks with feature selection for gdp per capita estimation based on academic parameters. Comput. Syst. Sci. Eng. 2019, 34, 145-150.

22. Xue, Y.; Li, Q.; Ling, F. Teensensor: Gaussian processes for micro-blog based teen's acute and chronic stress detection. Comput. Syst. Sci. Eng. 2019, 34, 151-164. [CrossRef]

23. Xu, Z. Applications and Techniques in Cyber Intelligence. Comput. Syst. Sci. Eng. 2019, 34, 169-170. [CrossRef] 
24. Chubo, L.; Kenli, L.; Keqin, L. A Game Approach to Multi-Servers Load Balancing with Load-Dependent Server Availability Consideration. IEEE Trans. Cloud Comput. 2021, 9, 1-13.

25. Chubo, L.; Kenli, L.; Keqin, L.; Rajkumar, B. A New Service Mechanism for Profit Optimizations of a Cloud Provider and Its Users. IEEE Trans. Cloud Comput. 2021, 9, 14-26.

26. Hu, X.; Xie, J.; Cai, W.; Wang, R.; Davarpanah, A. Thermodynamic effects of cycling carbon dioxide injectivity in shale reservoirs. J. Pet. Sci. Eng. 2020, 195, 107717. [CrossRef]

27. Guoqing, X.; Kenli, L.; Yuedan, C.; Wangquan, H.; Albert, Y.; Zomaya, T.L. CASpMV: A Customized and Accelerative SpMV Framework for the Sunway TaihuLight. IEEE Trans. Parallel Distributed Syst. 2021, 32, 131-146.

28. Chu, S.; Majumdar, A. Opportunities and challenges for a sustainable energy future. Nature 2012, 488, 294-303. [CrossRef] [PubMed]

29. Hatami, E.; Toghraei, A.; Darband, G.B. Electrodeposition of Ni-Fe micro/nano urchin-like structure as an efficient electrocatalyst for overall water splitting. Int. J. Hydrogen Energy 2021, 46, 9394-9405. [CrossRef]

30. Xia, J.; Chen, H.; Li, Q.; Zhou, M.; Chen, L.; Cai, Z.; Fang, Y.; Zhou, H. Ultrasound-based differentiation of malignant and benign thyroid Nodules: An extreme learning machine approach. Comput. Methods Programs Biomed. 2017, 147, 37-49. [CrossRef]

31. Chen, H.; Wang, G.; Ma, C.; Cai, Z.-N.; Liu, W.-B.; Wang, S.-J. An efficient hybrid kernel extreme learning machine approach for early diagnosis of Parkinson's disease. Neurocomputing 2016, 184, 131-144. [CrossRef]

32. Shen, L.; Chen, H.; Yu, Z.; Kang, W.; Zhang, B.; Li, H.; Yang, B.; Liu, D. Evolving support vector machines using fruit fly optimization for medical data classification. Knowl.-Based Syst. 2016, 96, 61-75. [CrossRef]

33. Chen, L.; Xu, J.; Zhang, M.; Rong, T.; Jiang, Z.; Li, P. Systematic study on mechanical and electronic properties of ternary VAlN, TiAlN and WAlN systems by first-principles calculations. Ceram. Int. 2020, 47, 7511-7520. [CrossRef]

34. Wang, X.; Feng, Z.; Xiao, B.; Zhao, J.-X.; Ma, H.; Tian, Y.; Pang, H.; Tan, L. Polyoxometalate-based metal-organic frameworkderived bimetallic hybrid materials for upgraded electrochemical reduction of nitrogen. Green Chem. 2020, 22, 6157-6169. [CrossRef]

35. Zhang, Y.; Hao Nan, L.I.; Changhe, L.I.; Chuanzhen, H.; Hafiz Muhammad, A.; Xuefeng, X.; Cong, M.; Wenfeng, D.; Xin, C.; Min, Y.; et al. Nano-enhanced biolubricant in sustainable manufacturing: From processability to mechanisms. Friction 2021, in press. [CrossRef]

36. Shi, C.; Zhang, X.; Zhang, X.; Chen, P.; Xu, L. Ultrasonic desulfurization of amphiphilic magnetic-Janus nanosheets in oil-water mixture system. Ultrason. Sonochemistry 2021, 76, 105662. [CrossRef] [PubMed]

37. Mingxing, D.; Kenli, L.; Keqin, L.; Qi, T. A Novel Multi-task Tensor Correlation Neural Network for Facial Attribute Prediction. ACM Trans. Intell. Syst. Technol. 2021, 12,1-22.

38. Cen, C.; Kenli, L.; Sin, G.; Xiaofeng, Z.T.; Keqin, L.; Zeng, Z. Citywide Traffic Flow Prediction Based on Multiple Gated Spatio-temporal Convolutional Neural Networks. ACM Trans. Knowl. Discov. Data 2020, 14, 1-23.

39. Zhou, X.; Kenli, L.; ZhiBang, Y.; Gao, Y.; Keqin, L. Efficient Approaches to k Representative G-Skyline Queries. ACM Trans. Knowl. Discov. Data 2020, 14, 1-27. [CrossRef]

40. Davarpanah, A.; Mirshekari, B. Experimental Investigation and Mathematical Modeling of Gas Diffusivity by Carbon Dioxide and Methane Kinetic Adsorption. Ind. Eng. Chem. Res. 2019, 58, 12392-12400. [CrossRef]

41. Valizadeh, K.; Farahbakhsh, S.; Bateni, A.; Zargarian, A.; Davarpanah, A.; Alizadeh, A.; Zarei, M. A parametric study to simulate the non-Newtonian turbulent flow in spiral tubes. Energy Sci. Eng. 2020, 8, 134-149. [CrossRef]

42. Hu, L.; Hong, G.; Ma, J.; Wang, X.; Chen, H. An efficient machine learning approach for diagnosis of paraquat-poisoned patients. Comput. Biol. Med. 2015, 59, 116-124. [CrossRef]

43. Xu, X.; Chen, H.-L. Adaptive computational chemotaxis based on field in bacterial foraging optimization. Soft Comput. 2013, 18, 797-807. [CrossRef]

44. Zhang, Y.; Liu, R.; Wang, X.; Chen, H.; Li, C. Boosted binary Harris hawks optimizer and feature selection. Eng. Comput. 2020, 1-30. [CrossRef]

45. Karbakhshzadeh, A.; Derakhshande, M.; Farhami, M.; Hosseinian, A.; Ebrahimiasl, S.; Ebadi, A. Study the adsorption of letrozole drug on the silicon doped graphdiyne monolayer: A DFT investigation. Silicon 2021, 10, 1-8.

46. Sun, H.; Ebadi, A.G.; Toughani, M.; Nowdeh, S.A.; Naderipour, A.; Abdullah, A. Designing Framework of Hybrid PhotovoltaicBiowaste Energy System with Hydrogen Storage Considering Economic and Technical Indices Using Whale Optimization Algorithm. Energy 2021, 238, 121555. [CrossRef]

47. Sabeen, M.; Mahmood, Q.; Ebadi, A.G.; Bhatti, Z.A.; Irshad, M.; Kakar, A.; Bilal, M.; Arshad, H.M.; Shahid, N. Health risk assessment consequent to wastewater irrigation in Pakistan. Soil Environ. 2020, 39, 67-76. [CrossRef]

48. Renbing, Q.; Shujun, W.; Fengjuan, X. Structural Changes and in vitro Enzymatic Diges tibility of Starch-Lipid Complexes Altered by High Hydrostatic Pressure. J. Food Res. Dev. 2021, 42, 25-30.

49. Nejad, R.M.; Liu, Z.; Ma, W.; Berto, F. Reliability analysis of fatigue crack growth for rail steel under variable amplitude service loading conditions and wear. Int. J. Fatigue 2021, 106450. [CrossRef]

50. Nejad, R.M.; Liu, Z.; Ma, W.; Berto, F. Fatigue reliability assessment of a pearlitic Grade 900A rail steel subjected to multiple cracks. Eng. Fail. Analysis 2021, 105625. [CrossRef]

51. Wang, J.; Gao, Y.; Yin, X.; Li, F.; Kim, H.-J. An Enhanced PEGASIS Algorithm with Mobile Sink Support for Wireless Sensor Networks. Wirel. Commun. Mob. Comput. 2018, 2018, 1-9. [CrossRef] 
52. Liao, Z.; Wang, J.; Zhang, S.; Cao, J.; Min, G. Minimizing Movement for Target Coverage and Network Connectivity in Mobile Sensor Networks. IEEE Trans. Parallel Distrib. Syst. 2014, 26, 1971-1983. [CrossRef]

53. Wang, J.; Gao, Y.; Liu, W.; Sangaiah, A.K.; Kim, H.-J. An intelligent data gathering schema with data fusion supported for mobile sink in wireless sensor networks. Int. J. Distrib. Sens. Netw. 2019, 15. [CrossRef]

54. Zhang, J.; Jin, X.; Sun, J.; Wang, J.; Sangaiah, A.K. Spatial and semantic convolutional features for robust visual object tracking Multimedia Tools Appl. 2018, 79, 15095-15115. [CrossRef]

55. Yu, F.; Liu, L.; Xiao, L.; Li, K.; Cai, S. A robust and fixed-time zeroing neural dynamics for computing time-variant nonlinear equation using a novel nonlinear activation function. Neurocomputing 2019, 350, 108-116. [CrossRef]

56. Zhang, Y.; Liu, R.; Heidari, A.A.; Wang, X.; Chen, Y.; Wang, M.; Chen, H. Towards augmented kernel extreme learning models for bankruptcy prediction: Algorithmic behavior and comprehensive analysis. Neurocomputing 2020, 430, 185-212. [CrossRef]

57. Zhao, D.; Liu, L.; Yu, F.; Heidari, A.A.; Wang, M.; Liang, G.; Muhammad, K.; Chen, H. Chaotic random spare ant colony optimization for multi-threshold image segmentation of 2D Kapur entropy. Knowl.-Based Syst. 2020, 216, 106510. [CrossRef]

58. Tu, J.; Chen, H.; Liu, J.; Heidari, A.A.; Zhang, X.; Wang, M.; Ruby, R.; Pham, Q.-V. Evolutionary biogeography-based whale optimization methods with communication structure: Towards measuring the balance. Knowl.-Based Syst. 2020, $212,106642$. [CrossRef]

59. Deng, Z.; Liu, C.; Zhu, Z. Inter-hours rolling scheduling of behind-the-meter storage operating systems using electricity price forecasting based on deep convolutional neural network. Int. J. Electr. Power Energy Syst. 2020, 125, 106499. [CrossRef]

60. Deng, Z.; Wang, B.; Xu, Y.; Xu, T.; Liu, C.; Zhu, Z. Multi-Scale Convolutional Neural Network With Time-Cognition for Multi-Step Short-Term Load Forecasting. IEEE Access 2019, 7, 88058-88071. [CrossRef]

61. Wang, J.; Gu, X.; Liu, W.; Sangaiah, A.K.; Kim, H.-J. An empower hamilton loop based data collection algorithm with mobile agent for WSNs. Human-centric Comput. Inf. Sci. 2019, 9, 18. [CrossRef]

62. Li, W.; Chen, Z.; Gao, X.; Liu, W.; Wang, J. Multimodel Framework for Indoor Localization Under Mobile Edge Computing Environment. IEEE Internet Things J. 2018, 6, 4844-4853. [CrossRef]

63. Xiang, L.; Shen, X.; Qin, J.; Hao, W. Discrete Multi-graph Hashing for Large-Scale Visual Search. Neural Process. Lett. 2019, 49, 1055-1069. [CrossRef]

64. Zhang, J.; Wang, W.; Lu, C.; Wang, J.; Sangaiah, A.K. Lightweight deep network for traffic sign classification. Annals Telecom. 2019, 75, 369-379. [CrossRef]

65. Zhou, S.-R.; Yin, J.-P.; Zhang, J.-M. Local binary pattern (LBP) and local phase quantization (LBQ) based on Gabor filter for face representation. Neurocomputing 2013, 116, 260-264. [CrossRef]

66. Hsieh, T.H.; Lin, H.; Liu, J.; Duan, W.; Bansil, A.; Fu, L. Topological crystalline insulators in the SnTe material class. Nat. Commun. 2012, 3, 982. [CrossRef] [PubMed]

67. Khiarak, B.N.; Hasanzadeh, M.; Mojaddami, M.; Far, H.S.; Simchi, A. In situ synthesis of quasi-needle-like bimetallic organic frameworks on highly porous graphene scaffolds for efficient electrocatalytic water oxidation. Chem. Commun. 2020, 56, 3135-3138.

68. Huang, J.; Duan, T.; Zhang, Y.; Liu, J.; Zhang, J.; Lei, Y. Predicting the Permeability of Pervious Concrete Based on the Beetle Antennae Search Algorithm and Random Forest Model. Adv. Civ. Eng. 2020, 2020, 1-11. [CrossRef]

69. Huang, J.; Kumar, G.S.; Ren, J.; Sun, Y.; Li, Y.; Wang, C. Towards the potential usage of eggshell powder as bio-modifier for asphalt binder and mixture: Workability and mechanical properties. Int. J. Pavement Eng. 2021, 1-13. [CrossRef]

70. Shan, W.; Qiao, Z.; Heidari, A.A.; Chen, H.; Turabieh, H.; Teng, Y. Double adaptive weights for stabilization of moth flame optimizer: Balance analysis, engineering cases, and medical diagnosis. Knowl.-Based Syst. 2020, 214, 106728. [CrossRef]

71. Yu, C.; Chen, M.; Cheng, K.; Zhao, X.; Ma, C.; Kuang, F.; Chen, H. SGOA: Annealing-behaved grasshopper optimizer for global tasks. Eng. Comput. 2021, 1-28. [CrossRef]

72. Hu, J.; Chen, H.; Heidari, A.A.; Wang, M.; Zhang, X.; Chen, Y.; Pan, Z. Orthogonal learning covariance matrix for defects of grey wolf optimizer: Insights, balance, diversity, and feature selection. Knowl.-Based Syst. 2020, 213, 106684. [CrossRef]

73. Huang, J.; Zhang, Y.; Sun, Y.; Ren, J.; Zhao, Z.; Zhang, J. Evaluation of pore size distribution and permeability reduction behavior in pervious concrete. Constr. Build. Mater. 2021, 290, 123228. [CrossRef]

74. Zhou, J.; Shen, X.; Qiu, Y.; Li, E.; Rao, D.; Shi, X. Improving the efficiency of microseismic source locating using a heuristic algorithm-based virtual field optimization method. Geomech. Geophys. Geo-Energy Geo-Resour. 2021, 7, 1-18. [CrossRef]

75. Zhou, J.; Chen, C.; Wang, M.; Khandelwal, M. Proposing a novel comprehensive evaluation model for the coal burst liability in underground coal mines considering uncertainty factors. Int. J. Min. Sci. Technol. 2021, 1-15. [CrossRef]

76. Zhou, J.; Qiu, Y.; Khandelwal, M.; Zhu, S.; Zhang, X. Developing a hybrid model of Jaya algorithm-based extreme gradient boosting machine to estimate blast-induced ground vibrations. Int. J. Rock Mech. Min. Sci. 2021, 145, 104856. [CrossRef]

77. Zhou, J.; Li, X.; Mitri, H.S. Classification of Rockburst in Underground Projects: Comparison of Ten Supervised Learning Methods. J. Comput. Civ. Eng. 2016, 30, 04016003. [CrossRef]

78. Xiong, B.; Yang, K.; Zhao, J.; Li, W.; Li, K. Performance evaluation of OpenFlow-based software-defined networks based on queueing model. Comput. Netw. 2016, 102, 172-185. [CrossRef]

79. Wang, J.; Yang, Y.; Wang, T.; Sherratt, R.S.; Zhang, J. Big data service architecture: A survey. J. Internet Technol. 2020, 21, 393-405.

80. He, S.; Xie, K.; Xie, K.; Xu, C.; Wang, J. Interference-Aware Multisource Transmission in Multiradio and Multichannel Wireless Network. IEEE Syst. J. 2019, 13, 2507-2518. [CrossRef] 
81. Zhang, D.; Yin, T.; Yang, G.; Xia, M.; Li, L.; Sun, X. Detecting image seam carving with low scaling ratio using multi-scale spatial and spectral entropies. J. Vis. Commun. Image Represent. 2017, 48, 281-291. [CrossRef]

82. Long, M.; Peng, F.; Li, H.-Y. Separable reversible data hiding and encryption for HEVC video. J. Real-Time Image Process. 2017, 14, 171-182. [CrossRef]

83. Ortel, E.; Reier, T.; Strasser, P.; Kraehnert, R. Mesoporous IrO2 films templated by PEO-PB-PEO block-copolymers: Self-assembly, crystallization behavior, and electrocatalytic performance. Chem. Mater. 2011, 23, 3201-3209. [CrossRef]

84. Zhang, J.; Zhong, S.; Wang, T.; Chao, H.C.; Wang, J. Blockchain-based systems and applications: A survey. J. Internet Technol. 2020, $21,1-14$.

85. Tang, Q.; Yang, K.; Zhou, D.; Luo, Y.-S.; Yu, F. A Real-Time Dynamic Pricing Algorithm for Smart Grid With Unstable Energy Providers and Malicious Users. IEEE Internet Things J. 2015, 3, 554-562. [CrossRef]

86. He, S.; Zeng, W.; Xie, K.; Yang, H.; Lai, M.; Su, X. PPNC: Privacy preserving scheme for random linear network coding in smart grid. KSII Transac. Internet Inform. Syst. 2017, 11, 1510-1532.

87. Liang, Y.; Li, Y.; Wang, H.; Zhou, J.; Wang, J.; Regier, T.; Dai, H. Co3O4 nanocrystals on graphene as a synergistic catalyst for oxygen reduction reaction. Nature Mater. 2011, 10, 780-786. [CrossRef] [PubMed]

88. Zhao, X.; Li, D.; Yang, B.; Ma, C.; Zhu, Y.; Chen, H. Feature selection based on improved ant colony optimization for online detection of foreign fiber in cotton. Appl. Soft Comput. 2014, 24, 585-596. [CrossRef]

89. Yu, H.; Li, W.; Chen, C.; Liang, J.; Gui, W.; Wang, M.; Chen, H. Dynamic Gaussian bare-bones fruit fly optimizers with abandonment mechanism: Method and analysis. Eng. Comput. 2020, 1-29. [CrossRef]

90. Zheng, L.; Zheng, S.; Wei, H.; Du, L.; Zhu, Z.; Chen, J.; Yang, D. Palladium/bismuth/copper hierarchical nano-architectures for efficient hydrogen evolution and stable hydrogen detection. ACS Appl. Mater. Interfaces 2019, 11, 6248-6256. [CrossRef]

91. Wang, S.; Xue, W.; Fang, Y.; Li, Y.; Yan, L.; Wang, W.; Zhao, R. Bismuth activated succulent-like binary metal sulfide heterostructure as a binder-free electrocatalyst for enhanced oxygen evolution reaction. J. Colloid Interface Sci. 2020, 573, 150-157. [CrossRef] [PubMed]

92. Khiarak, B.N.; Golmohammad, M.; Shahraki, M.M.; Simchi, A. Facile synthesis and self-assembling of transition metal phosphide nanosheets to microspheres as a high-performance electrocatalyst for full water splitting. J. Alloys Compd. 2021, 875, 160049. [CrossRef]

93. Al-Odail, F.A.; Anastasopoulos, A.; Hayden, B.E. Hydrogen evolution and hydrogen oxidation on palladium bismuth alloys. Top. Catal. 2011, 54, 77-82. [CrossRef]

94. Zhou, L.; Yang, T.; Chen, S.; Gao, J.; Wang, X.; He, P.; Lei, H.; Yang, D.; Dong, F.; Jia, L.; et al. Tunably fabricated nanotremella-like Bi2S3/MoS2: An excellent and highly stable electrocatalyst for alkaline hydrogen evolution reaction. Int. J. Hydrogen Energy 2020, 45, 9535-9545. [CrossRef]

95. Chen, S.; Qiao, S.-Z. Hierarchically porous nitrogen-doped graphene-NiCo2O4 hybrid paper as an advanced electrocatalytic water-splitting material. ACS Nano 2013, 7, 10190-10196. [CrossRef]

96. Khiarak, B.N.; Hasanzadeh, M.; Simchi, A. Electrocatalytic hydrogen evolution reaction on graphene supported transition metal-organic frameworks. Inorg. Chem. Commun. 2021, 127, 108525. [CrossRef]

97. Li, Y.; Zhou, W.; Wang, H.; Xie, L.; Liang, Y.; Wei, F.; Idrobo, J.-C.; Pennycook, S.J.; Dai, H. An oxygen reduction electrocatalyst based on carbon nanotube-graphene complexes. Nat. Nanotechnol. 2012, 7, 394-400. [CrossRef]

98. Erlin, T.; Ebadi, A.G.; Mavaluru, D.; Alshehri, M.; Mohamed, A.A.; Sobhani, B. Parameter derivation of a proton exchange membrane fuel cell based on coevolutionary ribonucleic acid genetic algorithm. Comput. Intell. 2019, 35, 1021-1041. [CrossRef]

99. Zhao, S.; Li, C.; Liu, J.; Liu, N.; Qiao, S.; Han, Y.; Huang, H.; Liu, Y.; Kang, Z. Carbon quantum dots/SnO2-Co3O4 composite for highly efficient electrochemical water oxidation. Carbon 2015, 92, 64-73. [CrossRef]

100. Jiang, N.; Ebadi, A.G.; Kishore, K.H.; Yousif, Q.A.; Salmani, M. Thermomechanical reliability assessment of solder joints in a photovoltaic module operated in a hot climate. IEEE Trans. Compon. Packag. Manuf. Technol. 2019, 10, 160-167. [CrossRef]

101. Tian, M.W.; Ebadi, A.G.; Jermsittiparsert, K.; Kadyrov, M.; Ponomarev, A.; Javanshir, N.; Nojavan, S. Risk-based stochastic scheduling of energy hub system in the presence of heating network and thermal energy management. Appl. Therm. Eng. 2019, 159, 113825. [CrossRef]

102. Ebadi, A.G.; Hisoriev, H. Gasification of algal biomass (Cladophora glomerata L.) with $\mathrm{CO}_{2} / \mathrm{H}_{2} \mathrm{O} / \mathrm{O}_{2}$ in a circulating fluidized bed. Environ. Technol. 2019, 40, 749-755. [CrossRef]

103. Ebadi, A.G.; Hisoriev, H.; Zarnegar, M.; Ahmadi, H. Hydrogen and syngas production by catalytic gasification of algal biomass (Cladophora glomerata L.) using alkali and alkaline-earth metals compounds. Environ. Technol. 2019, 40, 1178-1184. [CrossRef] [PubMed]

104. Ebadi, A.G.; Hisoriev, H. Metal pollution status of Tajan River-Northern Iran. Toxicol. Environ. Chem. 2017, 99, 1358-1367. [CrossRef]

105. Ebadi, A.G.; Hisoriev, H. Physicochemical characterization of sediments from Tajan river basin in the northern Iran. Toxicol. Environ. Chem. 2018, 100, 540-549. [CrossRef]

106. Ebadi, A.G.; Hisoriev, H. The prevalence of heavy metals in Cladophora glomerata L. from Farahabad Region of Caspian Sea-Iran. Toxicol. Environ.Chem. 2017, 99, 883-891. [CrossRef] 